\title{
Degree of monopoly and class struggle: political aspects of Kalecki's pricing and distribution theory
}

\author{
Fernando M. Rugitsky* \\ New School for Social Research, New York, USA, and Brazilian Center for Analysis and Planning (Cebrap), \\ São Paulo, Brazil
}

The aim of this paper is to analyse the concept of class struggle in Michal Kalecki's writings. First, his inclusion of trade unions' strength as one of the determining elements of the degree of monopoly is examined, taking into consideration Abba Lerner's formulation of the latter and its development by Kalecki. Then, the limits of this understanding of class struggle are pointed out from the standpoint of Karl Marx's conceptual distinction between labor and labor-power. Finally, a reinterpretation of Kalecki's 'Political aspects of full employment' is provided, indicating the broader conception of class struggle implicit in this work and its usefulness to a better understanding of capital-labor conflicts in contemporary capitalism.

Keywords: class struggle, degree of monopoly, mark-up pricing, income distribution, Kalecki, Marx

JEL codes: $B 50, B 51, D 40, E 25, J 50$

\section{INTRODUCTION}

As is often the case, economists have recently been pushed back to the issue of income and wealth inequalities by developments that took place outside academia. The current crisis and the wave of protests that followed its outbreak forced back to the center stage long-overdue debates on the fairness of the prevailing patterns of distribution. The rhetoric of a polarization between the richest 1 percent and the remaining 99 percent challenges the increasing concentration of income that has been taking place within most countries since at least the 1980s (Palma 2011; Duménil and Lévy 2004; Piketty and Saez 2003). ${ }^{1}$

Within heterodox economics, one particular branch of research seems particularly relevant to this issue. It focuses on the relation between distribution and macroeconomic performance, building on (and debating with) Michal Kalecki's pricing and

* This paper owes a great deal to Anwar Shaikh. I'm also especially indebted to Duncan Foley, for several discussions and ongoing support. I'd like to thank, in addition, Deepankar Basu, Johann Jaeckel, Gilberto Tadeu Lima, Fred Lee, Michalis Nikiforos, Marcos Nobre, Hyun Woong Park, K. Vela Velupillai, and two anonymous referees. Without Lucia Del Picchia's revision, this paper would be a lot less readable. Responsibility for the remaining errors is, of course, my own.

1. See also Giesen and Nobre (2010), where the authors put the issue of inequality (and of the multiple meanings of the concept) in a broader historical and political context. 
distribution theory. The appeal of Kalecki within heterodoxy is partly due to the fact that he can be considered John Maynard Keynes's radical incarnation. Having had contact with the work of Karl Marx and Rosa Luxemburg, the Polish economist formulated in the 1930s a theory of the determination of output that gave centrality to the role of demand, in line with what Keynes had contemporaneously been developing. However, despite the numerous similarities between their works, Kalecki always examined explicitly the theoretical implications of the division of the product between wages and profits, a point that was mostly disregarded in Keynes's writings. This not only represented an understandable emphasis in light of his intellectual roots and socialist convictions, but also, more importantly, opened the way to using his theory to address radical questions about income distribution in capitalist societies. ${ }^{2}$

In short, Kalecki's theory of pricing and distribution consisted of positing a link between what he called the 'degree of monopoly' of firms and the functional distribution of income. The former was the determinant of the pricing decisions of firms, which set their prices by marking-up their average prime costs (comprising wages and materials). The higher the degree of monopoly was, the larger the mark-up would be. After some effort to aggregate this theory to the industry level and to the whole economy, Kalecki (1965 [2009], p. 30) was able to maintain that the 'average' degree of monopoly (of the private sector) was one of the determinants of 'the relative share of wages in the gross income of the private sector,' along with some other factors like the ratio of the materials bill to the wage bill and the industrial composition. Thus, while the level of income was determined by demand, its division depended on what he called 'distribution factors,' especially the degree of monopoly (ibid., p. 47).

It has been suggested that this theory, if taken to explain the determination of aggregate profits, is misleading. It can be shown formally that, in the aggregate, firms cannot increase profits by raising their prices. ${ }^{3}$ That is, an increase in the 'average' degree of monopoly, which would lead to higher mark-ups, would simply lead to an increase in the price level, raising nominal aggregate profits, but keeping their real level constant. Larger profits would only be obtained if all prices were raised, but nominal wages were kept constant. This, however, is an indirect way of reducing real wages and it shows that the connection between the 'degree of monopoly' and the distribution of income depends, in fact, on the real wages paid by the firms, and not on the prices charged by them. In this sense, one could suggest, following Marx, that the mark-up is actually determined within the sphere of production, by the rate of surplus value, and not by price manipulations undertaken in the sphere of circulation. ${ }^{4}$ As an implication, the focus of the theory of distribution would have to shift from firms that buy cheap to sell dear to the conflict between capitalists and workers.

Two qualifications seem to be important. First, it could be argued that Kalecki resorted to the degree of monopoly in order to explain the distribution of income, but when the issue was aggregate profits, he claimed that they would be determined by capitalists' expenditure decisions (on consumption and investment goods): 'capitalists earn

2. On the influence of Marx's work on Kalecki, see Feiwel (1975, pp. 53-62) and Sawyer (1985, ch. 8, pp. 144-174). On the differences between Keynes and Kalecki, see Davidson (2000).

3. See chapter 6 of Shaikh's forthcoming book (2014). See also Steedman (1992, pp. 133136 and 143-144) and Gontijo (1991).

4. Foley (1986, p. 45), for instance, defines the 'mark-up on costs' as the product of the rate of surplus value and the composition of capital (the wage share of total costs). 
what they spend, and workers spend what they earn,' according to him. ${ }^{5}$ And this was derived from an unquestionable accounting identity, given his usual assumption that workers do not save. Kalecki's argument, however, is different. He always stated that the determination of aggregate demand (and, consequently, of aggregate profits) depends on the interaction between the expenditure decisions and the 'distribution factors,' including the degree of monopoly (1965 [2009], p. 47). ${ }^{6}$ Focusing only on the expenditure decisions would be insufficient. But even if this was Kalecki's argument, the real issue is that an accounting identity, even when it is correct, does not specify determination. So, aggregate profits are indeed equal to the sum of capitalists' expenditures, given his assumptions, but this does not mean that the latter determine the former. What lies beneath the identity is the belief that a larger aggregate demand (generated by larger consumption or investment) will necessarily be met by a larger supply. To meet this larger supply, however, it is implicitly assumed that the capitalists will be able to produce a larger amount of surplus value. And it is this additional surplus value that appears as larger aggregate profits. ${ }^{7}$

The second qualification is that this objection to the Kaleckian connection between degree of monopoly and distribution of income should not imply that firms could not individually decide the prices they would charge with the aim of increasing their profits. It implies only that this will not raise profits in the aggregate. It is certainly true, however, that active competition between firms, including price competition, will affect the distribution of total profits among them. ${ }^{8}$ One should only note, perhaps, that capitalist competition seems to be more about cutting than raising prices, contrary to what imperfect competition theories suggest. ${ }^{9}$

The crucial point seems to be that Kalecki's pricing theory, relying on the concept of a degree of monopoly, provides the basis for a theory of distribution that shifts the focus away from the struggle between capitalists and workers and towards imperfections in

5. To the best of my knowledge, Kaldor (1955-1956, p. 96) coined this famous definition of Kalecki's theory of distribution.

6. 'In this way capitalists' consumption and investment conjointly with the "distribution factors" determine workers' consumption and consequently the national output and employment. The national output will be pushed up to the point where profits carved out of it in accordance with the "distribution factors" are equal to the sum of capitalists' consumption and investment' (Kalecki 1965 [2009], p. 47).

7. Kalecki (1965 [2009], p. 46) himself might have stimulated this confusion between accounting identities and determination with the following passage: 'it is clear that capitalists may decide to consume and to invest more in a given period than in the preceding one, but they cannot decide to earn more. It is, therefore, their investment and consumption decisions which determine profits, and not vice versa.' Interestingly, Kalecki's analysis of the relation between profits and investment is inspired by Marx's schemes of reproduction, but Marx's aim with them was simply to examine the quantitative relations necessary to the reproduction of capitalism, not to determine how profits are created. See, for example, Marx (1894 [1981], p. 971-991), where he goes back to the schemes of reproduction developed in Volume 2 in order to analyse the issue of reproduction given the division of surplus-value between profit and rent (categories which were not yet developed in Volume 2).

8. Marx (1894 [1981], p. 1001) himself argued that '[a] monopoly price for certain commodities simply transfers a portion of the profit made by the other commodity producers to the commodities with the monopoly price.' He clarified, nevertheless, that this can lead to 'a local disturbance in the distribution of surplus-value among the various spheres of production, but ... leaves unaffected the limits of the surplus-value itself' (ibid., p. 1001). See also Kotz (1982, p. 5). I wish to thank Deepankar Basu for bringing this paper to my attention.

9. See Shaikh (1978, esp. pp. 240-246; 1980). 
firms' competitive process. Anyone acquainted with Kalecki's writings could wonder, however, how all his emphases on the bargaining power of workers would fit in this depiction of his theory. He often claimed that the "significance of the power of trade unions' would influence the degree of monopoly (see, for instance, Kalecki 1965 [2009], p. 17). This leads to the main issue of this paper: the tensions of his concept of degree of monopoly and the way he relates it to a certain understanding of class struggle. If his theory's focus on class is responsible for much of its appeal within heterodox economics, it is important to analyse the manner in which class struggle is actually conceived in his work and to debate the political implications of this conception. The relation between class struggle and degree of monopoly in his writings will be approached in the next section (Section 2). Then, the limits of this conception of class struggle will be dealt with, resorting to Marx's distinction between labor and labor-power (Section 3). Finally, it will be argued that a different understanding of class struggle from the one implied by his pricing and distribution theory can be found in his paper 'Political aspects of full employment' (Kalecki 1943), an understanding that could help the development of a fruitful analysis of capital-labor relations in contemporary capitalism (Section 4).

\section{DEGREE OF MONOPOLY: LERNER AND KALECKI}

Kalecki borrowed the phrase 'degree of monopoly' from Abba Lerner, who used it in his paper 'The concept of monopoly and the measurement of monopoly power' (1934). Lerner's article should be read in the context of the formulation of the theories of imperfect and monopolistic competition, by Joan Robinson and Edward Chamberlin, respectively, in the early 1930s. While critiques of the assumption of perfect competition were not entirely new, the great depression that had started in 1929 proved to be a big incentive to the development of theoretical alternatives to it. It was commonly believed at the time that the growing concentration of production in ever-larger corporations made the economy inflexible to market adjustment mechanisms and, thus, tended to transform ordinary fluctuations into deeper crises. ${ }^{10}$ The responsibility of economists was, according to this argument, providing new and sounder foundations to the understanding of capitalism, basing their theories on the widespread evidence of imperfections in the competitive process. Robinson and Chamberlin attempted to do precisely that. Lerner's (1934, pp. 165-175) intention, in its turn, was to go further and develop a measure of monopoly power that could be used in applied research. He called this measure 'degree of monopoly.'

After rejecting some alternative approaches to determine the degree of monopoly, based on the number of sellers of a particular commodity or on the 'proportion of the total supply [that] is controlled by one or a few individuals and organizations' (ibid., p. 166), for instance, Lerner suggested that the measure of monopoly power should be $\frac{P-C}{C}$, where $P$ is the price of the commodity and $C$ is its marginal cost. He noted that this ratio

looks like the inverse of the formula for the elasticity of demand. It differs from it only in that the item marginal cost replaces the item marginal receipts. In equilibrium as normally conceived marginal costs coincide with marginal receipts so that our formula becomes identical with the inverse of the elasticity of demand. (ibid., p. 169)

10. See, for instance, Pollock (1941, pp. 202-203) and the references mentioned therein. 
In his first article focused specifically on the determination of the distribution of income, Kalecki (1938b, p. 100) referred to Lerner and adopted his concept of degree of monopoly. He then used it to formulate the initial version of his theory of distribution, claiming that the average degree of monopoly is 'with great approximation' equal to ' $\mathrm{t}$ ] $\mathrm{he}$ relative share of gross capitalist income and salaries in the aggregate turnover [aggregate product]' (ibid., p. 102). In his subsequent writings, however, his definition of the degree of monopoly would be different. ${ }^{11}$ He began stating that the relation of a firm's prices to its costs could be formalized in the following way:

$$
p=m u+n \bar{p},
$$

where $p$ is the firm's price, $u$ is its unit prime cost, $\bar{p}$ is the weighted average price of all firms (weighted by the respective output and inclusive of the firm in question), and $m$ and $n$ are positive coefficients. ${ }^{12}$ Then he would argue that those two coefficients reflected 'what may be called the degree of monopoly of the firm's position' (Kalecki 1965 [2009], p. 13). In order to attain the average degree of monopoly of the whole industry, Kalecki would aggregate the individual firm's pricing equations and obtain the following:

$$
\bar{p}=\left(\frac{\bar{m}}{1-\bar{n}}\right) \bar{u}
$$

where $\bar{u}$ is the average unit prime cost, $\bar{m}$ is the weighted average of the coefficients $m$ (weighted by the prime costs of each firm), and $\bar{n}$ is the weighted average of the coefficients $n$ (weighted by respective outputs). The average degree of monopoly at the industry level would be defined, thus, as $\left(\frac{\bar{m}}{1-\bar{n}}\right)$.

While it has been argued that there is continuity in Kalecki's writings on pricing, most of the literature considers his efforts of the late 1930s and early 1940s (including his paper of 1938, mentioned above) to be an unsuccessful digression, in which he attempted to formulate his theory using the framework of neoclassical economic theory. ${ }^{13}$ For the purposes of the present paper, it is noteworthy that the two different versions presented above of the degree of monopoly can have different theoretical implications. The first one, borrowed from Lerner, implies that the degree of monopoly can only change if the price elasticity of demand for the good changes. This price elasticity could be related to the imperfection of competition - that is, to the monopoly power of the firm in question. Kalecki (1938b, p. 109) himself argued along these lines, stating that ' $[\mathrm{t}] \mathrm{he}$ degree of monopoly has undoubtedly a tendency to increase in the long run because of the progress of concentration. Many branches of industries become "oligopolistic"; and oligopolies are often transformed into cartels.' This progress of concentration

11. This later version first appeared in his Theory of Economic Dynamics (Kalecki 1965 [2009]), the first edition of which was published in 1954.

12. On the conditions imposed on the coefficients $m$ and $n$, see Asimakopulos (1975, pp. 317318 ) and Basile and Salvadori (1984-1985, pp. 254-255). The rationale of this equation was the following: 'The firm must make sure that the price does not become too high in relation to prices of other firms, for this would drastically reduce sales, and that the price does not become too low in relation to its average prime cost, for this would drastically reduce the profit margin' (Kalecki 1965 [2009], p. 12).

13. The argument against continuity is mainly due to Kriesler (1988). For the alternative position, see Basile and Salvadori (1984-1985; 1990-1991) and Carson (1990; 1996). 
would arguably decrease the price elasticity of demand and, thus, increase the firm's degree of monopoly.

It is of course true that this reasoning is not incompatible with the later formulation of the degree of monopoly, which does not rely on price elasticity of demand, but rather on the coefficients $m$ and $n$. One could argue precisely that what lies beneath these coefficients is the price elasticity of demand: the lower the latter, the greater the coefficients would be. However, when Kalecki (1965 [2009], pp. 17-18) examines what might lead to changes in the degree of monopoly, in his later works, he mentions four major factors. The first two - the process of concentration in industry and the development of sales promotion through advertising and selling agents - could be made compatible with his earlier definition of the degree of monopoly, by claiming that they would affect the price elasticity of demand. But the latter two - changes in the level of overheads in relation to prime costs and in the significance of the power of trade unions - are of a different nature. Their influence on the degree of monopoly cannot be through any impact they might have on the price elasticity of demand, but operates through their impact on the firm's costs. ${ }^{14}$ An increase in the level of overheads in relation to prime costs, for example, will put pressure on the profits of the firms, if they do not increase their prices. Their reaction to defend their profits - by raising prices - amounts to an increase in the degree of monopoly. In relation to the power of trade unions, his argument is even subtler:

The existence of powerful trade unions may tend to reduce the profit margins for the following reasons. A high ratio of profits to wages strengthens the bargaining position of trade unions in their demands for wage increases since higher wages are then compatible with 'reasonable profits' at existing price levels. If after such increases are granted prices should be raised, this would call forth new demands for wage increases. It follows that a high ratio of profits to wages cannot be maintained without creating a tendency towards rising costs. This adverse effect upon the competitive position of a firm or an industry encourages the adoption of a policy of lower profit margins. Thus, the degree of monopoly will be kept down to some extent by the activity of trade unions, and this the more the stronger the trade unions are. (ibid., p. 18)

The specifics of the bargaining between capitalists and workers will be analysed in the next section. Here, what should be noted is the significant broadening of the concept of degree of monopoly from Lerner's original formulation (and Kalecki's early use of it) to this later development. The lasting impression is that, through further investigation of the factors that could affect the relation between the prices and costs of a firm and the overall distribution of income, Kalecki was pushed to include more and more elements under the 'degree of monopoly' rubric. But the concept became misleading, due to its etymological meaning. Note, for instance, that two firms operating in identical markets in terms of their competitive pressures would have different degrees of monopoly if trade unions had different strengths in each of the markets. Probably due to these ambiguities, several economists preferred to do without the concept of degree

14. Another important issue about the relation between the two versions of his model is that, in the early one, he was assuming short-run profit maximization by the firms (which is implicit in the concept of a price elasticity of demand), while in the later version he dropped this assumption, stating that '[i]n view of the uncertainties faced in the process of price fixing it will not be assumed that the firm attempts to maximize its profits in any precise sort of manner' (Kalecki 1965 [2009], p. 12). On that, see Reynolds (1983, pp. 494-497). Carson (1990, pp. 151-152) interprets the quoted passage in a different way. 
of monopoly and to replace it with the concept of mark-up. ${ }^{15}$ The emphasis on the relation between average prime costs and prices is maintained, in this way, but it is no longer tied to the narrow limits of imperfect competition. Perhaps this explains why Kalecki (1970 [1971], p. 160) himself, in one of the last papers he wrote, did not use the concept of degree of monopoly, referring instead to a mark-up over direct (that is, prime) costs, which was dependent on 'competition.'

In any case, the point to be retained is that, while his work always reserved a distinct role for social classes (his applied work, for example, showed remarkably detailed and nuanced politico-economic interpretations in terms of classes ${ }^{16}$ ), his theory of distribution restricted class struggle to a secondary influence on the degree of monopoly. And this was already more than what was conceded in his earlier work, in which the distribution of income was entirely determined by 'conditions of imperfect competition and oligopoly' (Kalecki 1942, p. 121) ${ }^{17}$ Even in his paper titled 'Class struggle and the distribution of national income, (1970 [1971], p. 161), class struggle appears simply as a factor that can, through its pressure on firms' costs, restrain the mark-ups (that is, decrease the degree of monopoly, in his earlier terms). Concluding this paper, he argued that 'class struggle as reflected in trade-union bargaining may affect the distribution of national income,' but this is 'connected with widespread imperfect competition and oligopoly in capitalist system' and the shifts in distribution 'are contained in fairly narrow limits' (1970 [1971], p. 163). The question that remains is whether this is a fruitful representation of the relation between class struggle and the distribution of income.

\section{CLASS STRUGGLE: KALECKI AND MARX}

In order to assess Kalecki's argument, one shall examine more concretely the possible relations between class struggle and degree of monopoly, and their impact on the distribution of income. In the Theory of Economic Dynamics, Kalecki (1965 [2009], p. 28) arrives at the conclusion that the share of wages in value added, $w$, can be determined by the following equation:

$$
w=\frac{1}{1+(k-1)(j+1)}
$$

where $k$ is the average degree of monopoly, defined above as $\left(\frac{\bar{m}}{1-\bar{n}}\right)$, and $j$ is the ratio of the aggregate cost of materials to the wage bill. ${ }^{18}$ It is clear, then, that there is an inverse relationship between the degree of monopoly and the wage share.

15. See, for instance, Steedman (1992, p. 129). The main criticism of the concept of degree of monopoly has actually been that it is tautological. While this does not seem to be the case, Kalecki's ambiguous treatment of the concept might have led to such suspicions. On this debate, see Riach (1971, esp. pp. 50-53), Feiwel (1975, pp. 95-97), and Kriesler (1988, pp. 111-115). 16. See, for example, Kalecki (1938a; 1966 [1972]; 1967 [1972]).

17. According to Carson (1990, p. 146), 'the introduction of an influence of trade unions on pricing behavior in his 1954 and 1971 models' was the 'most notable' change in his analysis.

18. This would apply, according to him, to any industry and could be extended to the manufacturing sector as a whole by simply taking into account the impact of the industry composition on the average degree of monopoly and on the average ratio of the cost of materials to wages. Moreover, after briefly reviewing the issues involved in aggregating further to the whole economy, he concludes that the expression above would still provide a reasonable approximation: 'broadly speaking, 
Notice, first, that $k$ is equal to $\frac{\bar{p}}{\bar{u}}$, from Equation (2.1) above. So an increase in $k$, which would decrease the wage share (and, of course, increase the profit share), could be thought of as a result of an increase in the prices charged by firms while keeping their average prime costs constant. In a highly integrated economic system like any contemporary capitalist economy, however, firms cannot raise their selling prices in the aggregate while keeping their prime costs constant, because by raising their prices they are also raising the prices of the inputs they have to buy to go on producing. The output of one firm is the input of another (Steedman 1992, pp. 133-136 and 143-144). In this sense, assuming constant labor productivity (as Kalecki usually does), the only way for $\bar{p}$ to increase more than $\bar{u}$, so that $k$ and real aggregate profits can increase, reducing the wage share, is by keeping nominal wages fixed (or, at least, rising more slowly than prices), since nominal wages are also a part of the prime costs of the firms. As mentioned above, increasing aggregate profits in this way would depend on reducing real wages. But what could be the relation between the degree of monopoly of firms and their ability to reduce the workers' real wage?

Kalecki's writings suggest two possible answers. First, ignoring for the moment the effect of trade unions' strength, it can be seen that any change in the nominal wage will be followed by a proportional change in prices, if the degree of monopoly is constant. That is, if the workers demand, and manage to attain, a higher nominal wage, the firms will simply react by raising prices and keeping their real wages constant. Moreover, if the average degree of monopoly increases - due to increasing concentration, for instance - firms will be able to charge even higher prices and the workers will have to accept, as a consequence, lower real wages. This is an outcome, of course, of the fact that trade unions' strength is ignored and that the workers are, thus, powerless to react to any rise in the price level. ${ }^{19}$

Kalecki's effort to incorporate class struggle into his theory of distribution had the objective of avoiding the implausibility of the scenario above. He was certainly aware that with powerless workers there could be no struggle. So, taking into consideration the strength of trade unions, as he did from 1954 onwards, he could argue that firms would keep a lower ratio of price to average prime costs in order to avoid demands of wage increases generating a spiral of rising costs and prices (Kalecki 1965 [2009], p. 18; 1970 [1971], p. 161). The consequence of this reasoning is that the power of trade unions effectively imposes a limit on the degree of monopoly. Beyond this limit, increasing concentration will have no impact on the pricing of firms. Hence, the real wage would be dependent on class struggle, being determined by the degree of monopoly within the limits given by the trade unions' strength.

Evidently, there are still several elements that have a concrete bearing on class struggle that could be included in the analysis. The level of employment, the mediation of wage bargaining by the government and the pressure it exerts on workers and capitalists, the relative ease of capital and labor mobility are examples of factors that can

the degree of monopoly, the ratio of prices of raw materials to unit wage costs and industrial composition are the determinants of the relative share of wages in the gross income of the private sector' (1965 [2009], p. 30).

19. According to Shaikh (2004, p. 139), the assumption that 'the organizational or institutional strength of labor has no influence whatsoever on the path of real wages and on the level of the wage share' is a common characteristic of several macroeconomic approaches. Examining how the issue is dealt with on standard neoclassical, Keynesian, Harrodian, and Goodwin models, he concludes that '[t]he degree of labor strength in the struggle over wages has no effect at all' (ibid., p. 139). The Keynesian model he analyses resorts to Kalecki's pricing and distribution theory. 
reasonably be expected to shift the balance of power in the class struggle and, consequently, influence the real wage. But Kalecki's framework seems to be broad enough to incorporate them, allowing them to change the strength of trade unions, for instance. And, of course, a model of income distribution is necessarily a simplification of reality aimed at emphasizing its crucial aspects. The problem is that, by restricting the purview of the theory to the struggles over the real wage, Kalecki is placing all emphasis on a part of the class struggle that cannot be properly understood in isolation. Without resorting to the distinction between labor and labor-power, which Marx put at the core of his theory of value, the real object of the class struggle remains overcast.

The importance of this distinction can be clarified through a hypothetical scenario: assume that a firm is able to hire the workers it needs to produce the amount of output it desires at a wage that guarantees a profit share of value added that it finds acceptable, if the output can be sold at the price the firm plans to charge for it. Assume, however, that because of the conflicts over the organization of the labor process, workers shirk, producing only half of the output originally planned by the firm. In this case, even if it sells all the output at the expected price, the firm will see its profit jeopardized. What this scenario indicates is that, after the struggle over the definition of the wage (the price paid for the labor-power bought), class struggle is not over, it rather moves on to the 'hidden abode of production' (Marx 1867 [1976], p. 279), manifesting itself as the struggle over the organization of the labor process and over the amount of labor that will actually be done. The surplus effectively produced, which will be appropriated by the capitalists as their profits, will only be determined as a result of this entire process, and focusing only on its first part is insufficient.

Marx's distinction between labor and labor-power addresses precisely this problem. By labor-power, he means 'the aggregate of those mental and physical capabilities existing in the physical form, the living personality, of a human being, capabilities which he sets in motion whenever he produces a use-value of any kind' (ibid., p. 270) Labor, in its turn, refers to the actual 'use of labor-power' (ibid., p. 283), the consumption of these capabilities or potential to work. In a capitalist mode of production, labor-power is transformed into a commodity that the workers sell to the capitalists, but the production of surplus value depends on the actual labor done in the production process. ${ }^{20}$ In Harry Braverman's (1974, p. 54) words:

[W] hat the worker sells, and what the capitalist buys, is not an agreed amount of labor, but the power to labor over an agreed period of time [that is, labor-power]. This inability to purchase labor, which is an inalienable bodily and mental function, and the necessity to purchase the power to perform it, is so fraught with consequences for the entire capitalist mode of production that it must be investigated more closely.

The distinction mentioned above allows Marx to place class struggle at the center of his understanding of capitalism. And the object of the struggle between capitalists and workers is not restricted to the value by which the workers sell their labor-power, as suggested by Kalecki's theory, but crucially extends itself to the determination of how much labor will actually be done by the workers. More concretely, not only 'questions of hours and wages,' but also several issues 'such as the nature and intensity of the labor process, the application of machinery, labor conditions, social benefits, and

20. 'It is not labor which directly confronts the possessor of money on the commodity-market, but rather the worker. What the worker is selling is his labor-power' (Marx 1867 [1976], p. 677). Foley (1986, pp. 46-47) refers to this distinction between labor-power and labor as one of the 'basic points' of Marx's explanation of the origin of surplus value. 
workers' rights' are subject to class conflicts, which 'directly affect the ratio of necessary to surplus labor time' (Postone 1993, p. 318) The amount of surplus value produced in a capitalist economy (and also the level of aggregate profits) can only be understood taking these conflicts into consideration.

Furthermore, in Marx's theory, these struggles cannot simply be understood as isolated disputes that get settled at each round and then start anew, because they give directionality to capitalist development. Or, to resort to the contemporary jargon, they imply path-dependence. In fact, the pattern of the capitalist development of production is shaped, over time, by these struggles, with the consequence that workers and capitalists face at each stage conditions of production inherited from past developments. Historically, this resulted, according to Marx, in the transition of the organization of production from cooperation to manufacture and then to machine production. ${ }^{21}$ What he attempts to demonstrate is that the historical transformation of production is not a neutral development, technically determined, which is meant to increase overall productivity. While an immense increase in productivity does result from this development, its actual driving force is individual capitalists' incessant attempt to increase the rate of surplus value by decreasing the part of the working day that is actually paid to the workers. Technological development, in this sense, is inextricably linked to class struggle, since it aims not only to increase productivity, but also to shift the control of the labor process from the workers to the capitalists in order to allow the latter to impose ever-increasing levels of intensity of work on the former, speeding-up production to increase surplus value. ${ }^{22}$

This conception of capitalist development implies that the distribution of income between wages and profits cannot be explained by the historical trajectory of the real wage alone (or by the class struggle that determines this trajectory). It is the interaction between wages, technical progress, and the organization of production that structurally determines the division of the output between the capitalists and the workers. And class struggle lies behind each of these elements. It is in this sense that Postone (1993, p. 319) claims that '[c]lass conflict becomes a driving element of the historical development of capitalist society. ${ }^{23}$

It can be argued that this could easily be incorporated into Kalecki's theory of distribution, by allowing the degree of monopoly to be dependent on technical progress. ${ }^{24}$ If the former is equal to the ratio of price to unit prime costs, it is obvious that a shift in labor productivity could increase the degree of monopoly by reducing unit prime costs. However, once more, this goes against the etymological meaning of degree of monopoly and could be better conceived independently of this concept. More importantly, the theoretical relation between class struggle and the capitalist development of production, described above, suggests a profound effect of the former in the pattern of distribution of income that goes much beyond what Kalecki (1970 [1971], p. 163) concedes when he maintains that the impact of trade union bargaining on the distribution

21. See Marx (1867 [1976], chs 13-15, pp. 439-639).

22. On that, see also Foley (1986, pp. 57-60) and Gintis (1976, pp. 44-52).

23. It needs to be clarified, however, that Postone (1993, p. 345, fn 107) argues that, according to Marx, the 'historical trajectory' of capitalism 'cannot be explained with reference to class struggles alone.' According to him, 'class conflict does play an important role in the extension and dynamic of capitalism,' but 'it neither creates the totality nor gives rise to its trajectory' (ibid., p. 319).

24. Kaleckian models that make technical change endogenous could be interpreted as a step in this direction. See, for instance, You (1994), Cassetti (2003), and Lima (2004). 
of income depends entirely on the 'widespread imperfect competition and oligopoly in capitalist system.'

Finally, it is important to emphasize that this expanded conception of class struggle is not merely of academic interest; on the contrary, it is evident in the everyday struggles between capitalists and workers. A historical illustration from the time Kalecki was writing might help elucidate this point. Examining the labor relations in the US automobile industry from 1946 to 1970, Lichtenstein (1985) shows that the focus of the United Auto Workers' leadership on stable long-term bargaining processes over wages did not succeed in avoiding conflict at the shop-floor level, but simply shifted the object of dispute to local issues that were generally related to attempts by the management to speed-up production. Similarly, Betheil (1978), focusing on the US steel industry at about the same period, argues that the labor conflict revolved around the attempt by management to recover control over the organization of the labor process, which was, at the beginning of the period, tightly regulated by agreements that had been achieved by the trade union. Interestingly, the gradual advances of the employers, in this dispute, helped by the pressures on the trade union exerted by the government, seemed to be reinforced, from the mid 1960s on, by the generalization of newly-developed labor-saving technologies (ibid., pp. 16-17). An exclusive focus on the struggle over the wage would hinder a proper understanding of these two cases of class conflict.

\section{4 'KALECKIAN REACTIONS'}

The story, however, does not end here. A careful examination of Kalecki's understanding of class struggle would be incomplete if it overlooked his article published in 1943, titled 'Political aspects of full employment.' In this remarkable piece, he swims against the tide of the time, arguing that developing an economic theory about how government policy could achieve full employment was not enough to secure this latter outcome. He attempted to shatter the technocratic hopes of left-wing economists by analysing the reasons why capitalists would react against a full employment policy, or, as he put it, by analysing the 'political background in the opposition to the full employment policy' (Kalecki 1943, p. 324). This argument is, first of all, very important in the face of the fact that many current heterodox economists manifest disbelief in the insistence of governments to apply 'flawed' policies, based on the dominant economics, while the alternative theoretical framework they favor would suggest policies that are much more 'beneficial.' 'Beneficial' to whom is, of course, the relevant question, considering that policy decision is not merely a technical matter, but the outcome of concrete political struggles.

Kalecki (1943, pp. 324-326) claimed that the reasons why capitalists would oppose full employment policies could be divided into three categories. First, there is the obvious risk that government spending, increased as a means to obtain higher employment, would either compete with private investment (if it consisted of public investment) - putting pressure on profitability - or reduce the constraints on individual behavior that allow capitalist social relations to reproduce themselves (if it consisted of subsidizing mass consumption). Second, by making the level of employment independent of the level of private investment, full employment policies take from the capitalists what Kalecki considered a 'powerful controlling device' (ibid., p. 325). The link between the level of employment and 'the state of confidence' guarantees to 'the capitalists a powerful indirect control over Government policy' (ibid., p. 325), and weakening this link would consequently curtail this control. Third, the maintenance of full 
employment would entail 'social and political changes' that could put at risk 'discipline in the factories' and 'political stability' (ibid., p. 326). That is due to the fact that continuous full employment would reduce the disciplinary character, for workers, of the threat of being fired, which would undermine, according to him, 'the social position of the boss' at the same time as it would increase 'the self assurance and class consciousness of the working class' (ibid., p. 326).

This analysis suggests a much broader understanding of class struggle than the one attributed to Kalecki so far. But, instead of questioning the previous analysis of the relationship between degree of monopoly and class struggle, what this paper suggests is the existence of a tension within his work. It comes across as combining a very narrow conception of the struggle over the distribution of income, which only works through the channel of 'imperfect competition and oligopoly' (Kalecki 1970 [1971], p. 163), with a broader understanding of the political dimensions of capitalist development. This tension becomes all the clearer if one notices that, throughout the 1943 paper, Kalecki insists that the shifts in the balance of class power, in favor of the workers, that would result from a full employment policy would not reduce the profit rate, but would actually tend to increase it. Assuming, as he always did, that the economy is working below full capacity, he argues that the higher demand (generated by the full employment policy) would increase the capacity utilization and, thus, the profit rate. ${ }^{25}$ But this untenably relies on the exclusive determination of the profit share (and the profit rate) by the degree of monopoly, and its independence of the more general situation of class struggle (except, of course, through the indirect limiting effect that stronger trade unions impose on excessive mark-ups, according to him). So, even the lower 'discipline in the factories' that he anticipated as a consequence of continuous full employment would not likely risk profits, but would be opposed on strictly political grounds:

It is true that profits would be higher under a regime of full employment than they are on the average under laisser-faire; and even the rise in wage rates resulting from the stronger bargaining power of the workers is less likely to reduce profits than to increase prices, and thus affects adversely only the rentier interests. But 'discipline in the factories' and 'political stability' are more appreciated by the business leaders than profits. Their class instinct tells them that lasting full employment is unsound from their point of view and that unemployment is an integral part of the 'normal' capitalist system. (Kalecki 1943, p. 326)

A deeper understanding of the nature of class struggle in capitalist societies would allow him to question, however, whether this dilemma between 'discipline in the factories' and 'political stability,' on the one hand, and profits, on the other, is actually posed to 'business leaders.' It might be more accurate to consider that they try to guarantee shop-floor discipline and political stability in order to guarantee their profits. ${ }^{26}$

25. This is related to the debate on so-called growth and demand regimes (that is, whether growth and demand are wage- or profit-led). The present argument implies that the antagonistic nature of capitalist economies, evident in the broader concept of class struggle, is independent of the demand regime that characterizes them. Wage-led demand and growth regimes, if they exist in actual capitalism, do not transform class societies into cooperative idylls. For a sample of this literature, both theoretical and empirical, see Marglin and Bhaduri (1990), Taylor (1990), Blecker (2002), Barbosa-Filho and Taylor (2006), Foley and Taylor (2006), Naastepad and Storm (2006-2007), Hein and Vogel (2008), Hein and Tarassow (2010), Stockhammer and Stehrer (2011), and Nikiforos and Foley (2012).

26. The point is that the broader conception of class struggle suggested in the last section implies that shop-floor discipline and political stability are determinants of the rate of surplus 
Independently of this tension within his work, however, Kalecki's argument in the paper from 1943 suggests a fruitful extension of the analysis of class struggle sketched in the previous section. By emphasizing the connection between private investment and the level of employment, and by suggesting that this connection gave capitalists a 'powerful controlling device' over government policy, he points out another important instrument to which the capitalists resort in class struggle - an instrument that can be properly understood only within the framework of a theory in which aggregate demand plays a crucial role and in which the relation between the level of investment and the overall economic performance is emphasized. This political implication of Kalecki's analysis was recently picked up in a very important paper by Streeck (2011, p. 9), who reinterprets the mentioned controlling device as "Kaleckian reactions" of the owners of productive resources to democratic politics penetrating into their exclusive domain.' The nature of these reactions usually takes the form of 'an investment strike of capital owners' (ibid., p. 9, fn 5), which jeopardizes economic performance and, thus, pressures government to appease the capitalists, by complying with their demands and restoring, in this way, 'the "confidence" of investors' (ibid., p. 9, fn 5).

This means that capitalists do not restrict themselves, in the class struggle, to the usual means of firing workers and adopting labor-saving technologies. They may also face the workers through the mediation of the political realm, by pressing government to avoid shifting the balance of class power in favor of the working class, and even to shift it in their favor. One may argue that this is rather trivial, and that it is not even new from the perspective of a Marxian understanding of class struggle. After all, Marx and Engels (1848 [2010], p. 69) had already claimed, in the Manifesto of the Communist Party, that '[t]he executive of the modern [representative] state is but a committee for managing the common affairs of the whole bourgeoisie.' But, in my view, there is a crucial subtlety in Kalecki's argument that has implications beyond those usually debated on Marxian analyses of the state. ${ }^{27}$ The occurrence of the so-called 'Kaleckian reactions' is not simply the ever-present attempt of the capitalists to control government policies to their advantage, but it is a particular manifestation of this attempt that only comes into being in the postwar period and is remarkably anticipated by Kalecki in 1943.

The consolidation of liberal democracy in the aftermath of the Second World War, however limited its porosity to popular pressure, combined with the traumatic social and political experiences of the Great Depression of the 1930s, made governments particularly inclined to fight high rates of unemployment. ${ }^{28}$ The Employment Act of 1946, in the US, and similar labor market institutions established in Western Europe cannot be understood without bearing in mind the political developments of the interwar period, even if these legislations ended up significantly watered down by

value and, thus, affect the rate of profit. It could be true, however, as suggested by an anonymous referee, that discipline and stability could also be guaranteed by giving workers higher wages and consequently keeping a lower profit share. According to the referee, Kalecki could have been considering a distinction between short- and long-term goals: capitalists would give away part of their profits in the short term, in order to attain the discipline and stability that would reward them with larger profits in the long term. It is important to notice, however, that in the passage quoted above Kalecki is suggesting that capitalists might keep discipline and stability by weakening the workers with higher rates of unemployment, not by paying them higher wages.

27. For a summary of the different theories of the capitalist state formulated within the Marxian tradition, see Jessop (1977).

28. The political pressure on the governments of capitalist countries imposed by the existence of the Soviet Union, in the context of the Cold War, should also be mentioned. 
capitalists' pressure. ${ }^{29}$ Kalecki himself stated that 'it must be recognized that the stage in which the "business leaders" could afford to be opposed to any kind of Government interventions to alleviate a slump is rather a matter of the past. ${ }^{30}$ With hindsight, it is clear that the commitment to full employment was not bound to be permanent, with the neoliberal backlash managing to consolidate the view that not only capitalism has a 'natural rate of unemployment' - sometimes called NAIRU (non-accelerating inflation rate of unemployment) - but also that the only way to reduce this natural rate is to 'reform' labor market institutions, rolling back previous workers' victories. In spite of that, output growth rates and the level of employment still play an undoubtedly central role as criteria by which governments are assessed in everyday political disputes. ${ }^{31}$

The interesting implication of Kalecki's argument is that the determination of the level of employment and of the growth rate of the economy by capitalists' decisions to invest actually allows them to use to their advantage the constraint that democratic politics puts on the economic performance. Paradoxically, it is precisely because governments cannot afford, politically, levels of unemployment beyond certain limits (limits which are, of course, politically defined and liable to change) and deep and long recessions that they depend on capitalists' support of their policies and, ultimately, have to attend to their demands. The idea of 'Kaleckian reactions' means that the relative stabilization of the economy, which was originally a demand of the working classes, ended up empowering capitalists and might have even shifted the balance of class power in their direction. ${ }^{32}$ Tiring references in the public sphere to the oscillations of 'business confidence' or 'investor expectations' are actually indicators of the constant blackmailing of governments by capitalist groups, and remind bureaucrats of the permanent danger of a 'Kaleckian reaction' - that is, an investment strike of capital owners.

It has to be clear, however, that the emergence of this instrument of class struggle that is being called a 'Kaleckian reaction,' following Streeck (2011, p. 9), does not mean that the usual domain of the class struggle, inherent in the distinction between labor and labor-power, as analysed in the previous section, becomes secondary. However crucial the mediation of the social relations through the political realm is, it cannot

29. On that, see Armstrong et al. (1984 [1991], pp. 13-14) and Esping-Andersen (1990, ch. 7, pp. 162-190).

30. Just before his death, in 1970, Kalecki co-authored a paper with Tadeusz Kowalik (1971 [1991]), in which they argued that capitalism had gone through a 'crucial reform,' which was a consequence of the pressure of the masses but stopped short of abolishing existing relations of production. Such 'crucial reform,' which is presupposed in the present argument, may be understood as a politicization of the capitalist social relations, which enhanced the mediating role of the political realm in the reproduction of these social relations, as theorized for instance by Pollock (1941) and Habermas (1968 [1970]).

31. Current developments, especially in Europe, have been revealing a surprisingly large capacity of governments to impose an extraordinary degree of social violence, through austerity programs. But, at the same time, the deep political instability presently characterizing the Eurozone testifies to the limits that democracies (however restricted) impose on capitalism.

32. This might seem contradictory to Kalecki's claim that a full employment policy could weaken the link between 'business confidence' and the level of employment. In my opinion, he did overestimate the power of such a policy to maintain the stabilization of the economy through time independently of capitalists' support. If the latter reacted to a government policy by cutting back investment, the government would have to increase its expenditure further to compensate the effect of the lower investment on aggregate demand. The extension of the government's role could, then, lead to even lower investment, unleashing a degenerative cycle that could easily become unsustainable for an economy still organized on a capitalist basis. 
displace the role of the production and appropriation of surplus value, within the sphere of production, in reproducing these capitalist social relations. However powerful a capitalist might be in the political realm, she will not be able to remain a capitalist if she does not continually appropriate a share of the surplus value that the workers produce. In this sense, Kalecki's aforementioned disregard for the sphere of production in his distribution theory is problematic because it misses the main structural determinant of the reproduction of a capitalist society. But, moving from the abstract theoretical level to the concreteness of the political struggle, the broader conception of class struggle suggested here, which combines the struggle between capital and labor in the sphere of production with its unfolding in the political realm, appears to be important strategically. In the words of Thompson (1960, p. 68):

We do not have one 'basic antagonism' at the place of work, and a series of remoter, more muffled antagonisms in the social or ideological 'superstructure', which are in some way less 'real'. We have a class-divided society, in which conflicts of interest, and conflicts between capitalist and socialist ideas, values, and institutions take place all along the line. They take place in the health service and in the common room, and even - on rare occasions - on the television screen or in Parliament, as well as on the shop floor.

After more than 30 years of workers' defeats, in which income distribution has become increasingly unequal, the working class cannot afford to focus on a specific sphere, but has to face the capitalists 'all along the line.' Incorporating the idea of 'Kaleckian reactions' to the understanding of class struggle suggests the need for a transformation of the economic system that could disempower capitalists from this controlling device. More than 20 years ago, Marglin and Bhaduri (1990, p. 184), in a research program that led the way to the radical revision of the social-democratic consensus among left-wing economists, stated that what was needed was 'a much more radical break with the past, a new institutional structure that would decouple accumulation from profitability altogether.' ${ }^{33}$ This seems to be exactly what is required to give the decisive step to overcome the threat of 'Kaleckian reactions' and open the way to the democratic control of economic life.

\section{REFERENCES}

Armstrong, Philip, Glyn, Andrew, Harrison, John (1984 [1991]). Capitalism since 1945. Oxford: Basil Blackwell.

Asimakopulos, Athanasios (1975). 'A Kaleckian theory of income distribution.' Canadian Journal of Economics, 8 (3), 313-333.

Barbosa-Filho, Nelson, Taylor, Lance (2006). 'Distributive and demand cycles in the US economy: a structuralist Goodwin model.' Metroeconomica, 57 (3), 389-411.

Basile, Liliana, Salvadori, Neri (1984-1985). 'Kalecki's pricing theory.' Journal of Post Keynesian Economics, 7 (2), 249-262.

Basile, Liliana, Salvadori, Neri (1990-1991). 'Kalecki's pricing theory revisited.' Journal of Post Keynesian Economics, 13 (2), 293-297.

33. See Glyn (1995) for a similar argument. It is important to clarify that Kalecki remained skeptical of the possibility of attaining full employment or a more equal income distribution without a radical transformation of capitalism, as both his paper from 1943 and the paper he co-authored with Kowalik (1971 [1991]) suggest. Marglin and Bhaduri (1990) were not, then, reacting to his views, but rather to more optimistic social-democratic positions, some of them inspired by him. 
Betheil, Richard (1978). 'The ENA in perspective: the transformation of collective bargaining in the basic steel industry.' Review of Radical Political Economics, 10 (2), 1-24.

Blecker, Robert (2002). 'Distribution, demand and growth in neo-Kaleckian macro-models.' In: Setterfield, Mark (ed.). The Economics of Demand-led Growth: Challenging the Supply-side Vision of the Long Run. Northampton, MA: Edward Elgar, pp. 129-152.

Braverman, Harry (1974). Labor and Monopoly Capital: the Degradation of Work in the Twentieth Century. New York: Monthly Review Press.

Carson, John (1990). 'Kalecki's pricing theory revisited.' Journal of Post Keynesian Economics, $13(1), 146-152$.

Carson, John (1996). 'Kalecki's pricing theory: marginalist to the end?' History of Political Economy, 28 (4), 663-690.

Cassetti, Mario (2003). 'Bargaining power, effective demand and technical progress: a Kaleckian model of growth.' Cambridge Journal of Economics, 27 (3), 449-464.

Davidson, Paul (2000). 'There are major differences between Kalecki's theory of employment and Keynes's general theory of employment, interest and money.' Journal of Post Keynesian Economics, 23 (1), 3-25.

Duménil, Gérard, Lévy, Dominique (2004). 'Neoliberal income trends: wealth, class and ownership in the USA.' New Left Review, 30, 105-133.

Esping-Andersen, Gosta (1990). The Three Worlds of Welfare Capitalism. Princeton: Princeton University Press.

Feiwel, George (1975). The Intellectual Capital of Michal Kalecki: a Study in Economic Theory and Policy. Knoxville: University of Tennessee Press.

Foley, Duncan (1986). Understanding Capital: Marx's Economic Theory. Cambridge, MA: Harvard University Press.

Foley, Duncan, Taylor, Lance (2006). 'A heterodox growth and distribution model.' In: Salvadori, Neri (ed.). Economic Growth and Distribution: on the Nature and Causes of the Wealth of Nations. Northampton, MA: Edward Elgar, pp. 75-99.

Giesen, Klaus-Gerd, Nobre, Marcos (2010). 'World-system inequalities before and after the crisis.' Peace Review, 22 (4), 339-348.

Gintis, Herbert (1976). 'The nature of the labor exchange and the theory of capitalist production.' Review of Radical Political Economics, 8 (2), 36-54.

Glyn, Andrew (1995). 'Social democracy and full employment.' New Left Review, 211, 33-55.

Gontijo, Cláudio (1991). 'Grau de monopólio e determinação de preços em Kalecki: uma apreciação crítica.' Revista de Economia Política, 11 (2), 5-17.

Habermas, Jürgen (1968 [1970]). 'Technology and science as "ideology".' In: Habermas, Jürgen. Toward a Rational Society: Student Protest, Science, and Politics. Trans. Jeremy Shapiro. Boston: Beacon Press, pp. 81-122.

Hein, Eckhard, Tarassow, Artur (2010). 'Distribution, aggregate demand and productivity growth: theory and empirical results for six OECD countries based on a post-Kaleckian model.' Cambridge Journal of Economics, 34 (4), 727-754.

Hein, Eckhard, Vogel, Lena (2008). 'Distribution and growth reconsidered: empirical results for six OECD countries.' Cambridge Journal of Economics, 32 (3), 479-511.

Jessop, Bob (1977). 'Recent theories of the capitalist state.' Cambridge Journal of Economics, 1 (4), 353-373.

Kaldor, Nicholas (1955-1956). 'Alternative theories of distribution.' Review of Economic Studies, 23 (2), 83-100.

Kalecki, Michal (1938a). 'The lessons of the Blum experiment.' Economic Journal, 48 (189), 26-42.

Kalecki, Michal (1938b). 'The determinants of distribution of the national income.' Econometrica, 6 (2), 97-112.

Kalecki, Michal (1942). 'Mr. Whitman on the concept of "degree of monopoly" - a comment.' Economic Journal, 52 (205), 121-127.

Kalecki, Michal (1943). 'Political aspects of full employment.' Political Quarterly, 14 (4), 322-331.

Kalecki, Michal (1965 [2009]). Theory of Economic Dynamics: an Essay on Cyclical and Long-run Changes in Capitalist Economy. 2nd edn. New York: Augustus Kelley/Monthly Review Press. 
Kalecki, Michal (1966 [1972]). 'Intermediate regimes.' In: Kalecki, Michal. The Last Phase in the Transformation of Capitalism. New York: Monthly Review Press, pp. 115-124.

Kalecki, Michal (1967 [1972]). 'Vietnam and U.S. Big Business.' In: Kalecki, Michal. The Last Phase in the Transformation of Capitalism. New York: Monthly Review Press, pp. 107-114.

Kalecki, Michal (1970 [1971]). 'Class struggle and the distribution of national income.' In: Kalecki, Michal. Selected Essays on the Dynamics of the Capitalist Economy, 1933-1970. Cambridge, UK: Cambridge University Press, pp. 156-164.

Kalecki, Michal, Kowalik, Tadeusz (1971/1991). 'Observations on the "crucial reform".' In: Osiatynski, Jerzy (ed.). Collected Works of Michal Kalecki. Vol. II (Capitalism: Economic Dynamics). Trans. Chester A. Kisiel. Oxford: Clarendon Press, pp. 467-476.

Kotz, David (1982). 'Monopoly, inflation and economic crisis.' Review of Radical Political Economics, 14 (4), 1-17.

Kriesler, Peter (1988). 'Kalecki's pricing theory revisited.' Journal of Post Keynesian Economics, 11 (1), 108-130.

Lerner, Abba (1934). 'The concept of monopoly and the measurement of monopoly power.' Review of Economic Studies, 1 (3), 157-175.

Lichtenstein, Nelson (1985). 'UAW bargaining strategy and shop-floor conflict: 1946-1970.' Industrial Relations, 24 (3), 360-381.

Lima, Gilberto Tadeu (2004). 'Endogenous technological innovation, capital accumulation and distributional dynamics.' Metroeconomica, 55 (4), 386-408.

Marglin, Stephen, Bhaduri, Amit (1990). 'Profit squeeze and Keynesian theory.' In: Marglin, Stephen, Schor, Juliet (eds). The Golden Age of Capitalism: Reinterpreting the Postwar Experience. Oxford: Oxford University Press, pp. 153-186.

Marx, Karl (1867 [1976]). Capital: a Critique of Political Economy. Vol. 1. Trans. Ben Fowkes. London: Penguin Books.

Marx, Karl (1894 [1981]). Capital: a Critique of Political Economy. Vol. 3. Trans. David Fernbach. London: Penguin Books.

Marx, Karl, Engels, Frederick (1848 [2010]). 'Manifesto of the Communist Party.' In: Marx, Karl. The Revolutions of 1948: Political Writings Volume 1. New York: Verso, pp. 62-98.

Naastepad, C.W.M., Storm, Servaas (2006-2007). 'OECD demand regimes (1960-2000).' Journal of Post Keynesian Economics, 29 (2), 211-246.

Nikiforos, Michalis, Foley, Duncan (2012). 'Distribution and capacity utilization: conceptual issues and empirical evidence.' Metroeconomica, 63 (1), 200-229.

Palma, José Gabriel (2011). 'Homogeneous middles vs. heterogeneous tails, and the end of the "inverted-U": it's all about the share of the rich.' Development and Change, 42 (1), 87-153.

Piketty, Thomas, Saez, Emmanuel (2003). 'Income inequality in the United States, 1913-1998.' Quarterly Journal of Economics, 118 (1), 1-39.

Pollock, Friedrich (1941). 'State capitalism: its possibilities and limitations.' Studies in Philosophy and Social Science, 9 (2), 200-225.

Postone, Moishe (1993). Time, Labor, and Social Domination: a Reinterpretation of Marx's Critical Theory. New York: Cambridge University Press.

Reynolds, Peter (1983). 'Kalecki's degree of monopoly.' Journal of Post Keynesian Economics, 5 (3), 493-503.

Riach, Peter (1971). 'Kalecki's "degree of monopoly" reconsidered.' Australian Economic Papers, 10 (16), 50-60.

Sawyer, Malcolm (1985). The Economics of Michal Kalecki. New York: M.E. Sharpe.

Shaikh, Anwar (1978). 'Political economy and capitalism: notes on Dobb's theory of crisis.' Cambridge Journal of Economics, 2 (2), 233-251.

Shaikh, Anwar (1980). 'Marxian competition versus perfect competition: further comments on the so-called choice of technique.' Cambridge Journal of Economics, 4 (1), 75-83.

Shaikh, Anwar (2004). 'Labor market dynamics with rival macroeconomic frameworks.' In: Argyrous, George, Forstater, Matthew, Mongiovi, Gary (eds). Growth, Distribution and Effective Demand: Alternatives to Economic Orthodoxy. Armonk, NY: M.E. Sharpe, pp. 127-143. 
464 Review of Keynesian Economics, Vol. 1 No. 4

Shaikh, Anwar (2014). Modern Political Economy: Real Competition and Turbulent Macrodynamics. Forthcoming.

Steedman, Ian (1992). 'Questions for Kaleckians.' Review of Political Economy, 4 (2), 125-151.

Stockhammer, Engelbert, Stehrer, Robert (2011). 'Goodwin or Kalecki in demand? Functional income distribution and aggregate demand in the short run.' Review of Radical Political Economics, 43 (4), 506-522.

Streeck, Wolfgang (2011). 'The crises of democratic capitalism.' New Left Review, 71, 5-29.

Taylor, Lance (1990). 'Real and money wages, output and inflation in the semi-industrialized world.' Economica, 57 (227), 329-353.

Thompson, E.P. (1960). 'The point of production.' New Left Review, 1, 68-70.

You, Jong-Il (1994). 'Macroeconomic structure, endogenous technical change and growth.' Cambridge Journal of Economics, 18 (2), 213-233. 